\title{
Myles Brand: A Leader Deeply Committed to Diversity, Inclusiveness, and Social Justice
}

\author{
David K. Wiggins \\ George Mason University
}

Myles Brand will always be remembered as the man who fired legendary Indiana University basketball coach Bobby Knight. For many historical figures, both within and outside of sport, a highly publicized, singular event often defines their legacy. Such is the case with Brand. Brand's dispute with the controversial yet enormously well-known Knight has tended to obscure other, more consequential aspects of his career. This is unfortunate since Brand's professional accomplishments were many and varied. Born in Brooklyn, New York, and recipient of a BS degree in philosophy from Rensselaer Polytechnic Institute in 1964 and a Ph.D. in the same field from the University of Rochester in 1967, Brand fashioned a sterling academic career, first as an assistant professor and later as an upper-level administrator, including serving as president of two major Research I institutions (Brennan, 2009; Dunn et al., 2010; Hutchens, 2009; Pennington, 2009).

Brand's first academic position was as an assistant professor in the department of philosophy at the University of Pittsburgh, where he taught from 1967 to 1972. Following a five-year stint at Pittsburgh, Brand quickly climbed the academic ladder, assuming prestigious administrative positions at major universities, which underscores his superb leadership skills and ability to forge relationships and work effectively with people from various walks of life and backgrounds. He served as chair of the department of philosophy at the University of Illinois at Chicago from 1972 to 1981; head of the department of philosophy at the University of Arizona from 1981 to 1983; director of the Cognitive Science program at the University of Arizona from 1982 to 1985; dean of the faculty of social and behavioral sciences at the University of Arizona from 1983 to 1986; coordinating dean of the College of Arts and Sciences at the University of Arizona from 1985 to 1986; president of the University of Oregon from 1989 to 1994; and president of Indiana University from 1994 to 2002 (Brennan, 2009; Dunn et al., 2010; Hutchens, 2009; Pennington, 2009).

In 2003 Brand took on perhaps his most challenging administrative position. That year, he was hired as the $4^{\text {th }}$ President of the National Collegiate Athletic Association (NCAA), his first administrative position outside the formal university set- 
ting but one for which he was imminently qualified, based on his interests, skill set, and years of experience navigating the nexus between athletics and education. As the first of two university presidents to serve as President of the NCAA (the other being Mark Emmert, current NCAA President), Brand brought to the position a deep understanding of the complexities of intercollegiate sport, as well as a commitment to insuring its educational value and continued role as a positive force in university life. Importantly, not only did he oversee the high-profile athletic programs at two major universities, but he was also a student of sport who understood its history and the positive values and life lessons it could impart if organized and conducted properly (Lippold, 2007).

One of the best indications of Brand's thinking about intercollegiate athletics specifically and sport more generally can be gleaned from his January 23, 2001 presentation to members of the National Press Club in Washington, D.C. titled "Academics First: Reforming Intercollegiate Athletics" (Brand, 2001). Given just four months after Brand had fired Knight at Indiana University and about a year and a half before he assumed the position as President of the NCAA, the address laid out his philosophy of college sport to members of the National Press Club with honesty, forethought, and clarity. Basing his remarks, like any good academician, on both personal experience and the latest scholarly work, including James Shulman and William Bowen's The Game of Life (2001) as well as James Duderstadt's Intercollegiate Athletics and the American University; A President's Perspective (2000), Brand made clear his belief that major changes needed to be made in intercollegiate athletics. In particular, he pointed out what he termed was the "disconnect" between university presidents and the public at large. Most university presidents, noted Brand, believe their primary responsibility is to create and foster an environment in which new knowledge is uncovered, explained, and disseminated so as to make life more fulfilling, purposeful, and rewarding, while the general public believes "the most visible and vital role played by institutions such as IU is as a sponsor of athletic teams" (Brand, 2001, p. 367). Notwithstanding these comments, he laid blame for much of this "disconnect" at the feet of universities that had launched an athletic arms race characterized by the building of elaborate facilities, increasingly large expenditure budgets, and ballooning salaries for coaches and athletic directors - the effect of which "has led to the blending together of intercollegiate athletics with entertainment, which in turn has led to growing commercialization" (Brand, 2001, p. 368).

This commercialization, in Brand's view, jeopardized the mission of universities and, perhaps more importantly, "threaten[ed] to undermine the integrity of a system of higher education that has been widely acknowledged to be the best in the world" (Brand, 2001, p. 368). To deal with this issue, which was a crisis for Brand, especially regarding Division I football and men's basketball programs, a commitment should be made "to the academic mission and integrity of the university" while at once limiting the excesses of intercollegiate athletics "so that its positive features can flourish" (Brand, 2001, p. 369). Disputing those who either recommended the elimination of highly organized athletic programs and turning them into club sports or transforming them into an entirely professional endeavor, Brand contended instead 
that college sport needed to be reformed through a movement he titled Academics First. Leading the movement should be university presidents with assistance from athletic directors, coaches, governing boards, and the press. For Brand, one issue needing immediate attention was the dismal graduation rate in Division IA men's basketball, which at the national level in the late 1990s stood at $42 \%$, some $15 \%$ below the general student body. African American players fared the worst, with just $34 \%$ of them graduating within a six-year period. The remedy for this problem, as far as Brand was concerned, was not to make freshmen ineligible for athletic competition as some suggested, but to devise a system that did not force the most gifted players "to attend college just to meet their goal of playing professionally." Brand also recommended that authorities should examine ways to dramatically improve the K-12 academic preparation of student athletes. Ultimately for Brand, elevating graduation rates hinged on two factors: reassessing the K-12 academic preparation of student athletes and providing tutorial services that are fully "integrated into university-wide services" (Brand, 2001, pp. 370-371).

The pressing need for reform was not just idle chatter. Almost immediately after being appointed President of the NCAA on January 1, 2003, Brand began implementing various reforms designed to improve the academic preparation of student-athletes, increase their chances of graduating, and offer them a more meaningful and fulfilling college experience. Obvious throughout his nearly seven-year tenure as President was Brand's commitment to diversity, inclusiveness, and social justice. On many occasions, he noted that intercollegiate athletics and universities more generally should be committed to social justice and should provide everyone the opportunity to advance through the quality of their effort and natural ability. He remarked in 2008 "that social justice, advancement, success on the basis of hard work and actual ability, should be the only thing that counts - not skin color or gender" (Brand, 2008a, p. 9). On Brand's passing in 2009, Richard Lapchick, Chair of the DeVos Sport Business Management Graduate Program at the University of Central Florida and longtime advocate for racial equality in sport and society at large, poignantly wrote, "Like so many others, I lost a hero and a friend. Brand was a philosopher who will be remembered for his eloquence and for his fight for justice in sport, especially regarding graduation rates, gender equity, and diversity and inclusion" (Lapchick, 2009, p. 2).

One example of Brand's commitment to equality and social justice was the creation of the Office of Diversity and Inclusion at the NCAA, originally headed up by Charlotte Westerhaus, who is now an Indiana University Bicentennial Professor (Brand, 2007d; Kelley Indianapolis, 2019). Brand also tackled head-on the problem of academic preparation and graduation rates of athletes - a persistent concern in academic circles, to say the least, with African American athletes seemingly always at the center of it. Brand became NCAA President not too long after a series of reform measures were passed to improve the quality of education of student-athletes and thus increase their chances of graduating. In the 1980s and 1990s, on the heels of cheating scandals at several institutions and the stunning revelations of academic failures of such prominent African American athletes as Dexter Manley, Chris 
Washburn, and Kevin Ross, the NCAA instituted a number of propositions designed to eliminate cheating and elevate the academic performance of athletes. In 1983 the NCAA passed and implemented three years later Proposition 48, which required prospective athletes to achieve at least a 2.0 GPA in eleven core high school courses and a score of 700 on the SAT in order to become eligible for competition at the college level. Proposition 48 provoked intense debate, particularly among African Americans, many of whom, such as prominent basketball coaches John Thompson and Don Chaney, were outraged by the use of what they viewed as racially biased standardized test scores, while other well-known figures such as sociologist and civil rights activist Harry Edwards believed the minimum test scores would serve to incentivize Black athletes and improve their overall academic performance. In 1992, Proposition 48 was modified. The new measure, Proposition 16, created a sliding scale of SAT scores and a minimum high school GPA based on thirteen core courses rather than eleven (Coakley, 2021; Smith, 2011; Wiggins, 2018; Wiggins \& Miller, 2003).

Brand enthusiastically supported these reform measures. In fact, while he was NCAA President, the number of core courses determining eligibility was raised to 16. The data, though, were inconclusive. A study conducted by Richard Lapchick on behalf of the NCAA and released in March 2003 reported "that the academic achievements of many of the 16 men's basketball teams remaining in the N.C.A.A. tournament did not match their accomplishments on the court" (Litsky, 2003, p. S4). Based on data which assessed the number of basketball players who matriculated to college between 1992 and 1995 and had completed their degrees within six years, the graduation rates of African American players representing six of the 16 teams in the 2003 NCAA tournament "was a third to three-quarters lower than the rate for all male athletes" (p. S4). Of the sixteen teams, only Duke, Kansas, and Butler graduated at least two-thirds of its African American players. Six months later, however, the NCAA released a Department of Education report that undercut these findings. The report indicated that the graduation rate for all African American male athletes had risen to 48 percent, some 5 percentage points higher than the previous year. Moreover, the merged graduation rates of male and female African American athletes had risen to 52 percent, an increase of four percentage points from the previous year. And the graduation rates for African American male basketball players at the Division I level had climbed to 38 percent, an increase of two percentage points over the previous year.

The apparent improvement in the graduation rates of student-athletes, particularly among African American male and female student-athletes, albeit gleaned from data not always easy to decipher, was welcomed by Brand and indicated to him that the good news resulted from the reforms that had recently been implemented. Even so, Brand recognized much more work needed to be done. Soon, he appointed a committee to study the incentives and disincentives in place to hold schools accountable for the graduation rates of their student-athletes. The result was the creation of the Academic Progress Rate (APR), which was implemented for the first time in 2005. The APR, now utilized alongside the NCAA -created and -monitored Graduation Success Rate (GSR) and Coaches Academic Progress Rate (CAPR), was established 
to hold institutions accountable for the success of their student-athletes through a combination of academic metrics. Although there is little question that the APR has generally resulted in increased graduation rates, it has been heavily criticized by a broad spectrum of the American public, a fact that probably would have provoked the ire of Brand (Brand, 2006a; Drape, 2005; Hamilton, 2005; Hylton, 2009; Ositelu, 2019).

One particularly vocal collection of critics, The Drake Group, a network of academics who believe intercollegiate athletics has become too dominant a force on university campuses, assailed NCAA academic measures, contending that the reforms are merely "public relations 'smokescreens' hiding widespread exploitation of academically unprepared athletes and academic fraud by institutions chasing financial success in Division I sports" (Gurney et al., 2015, p.1). The group's major complaints were that the APR, and GSR and CAPR for that matter, did not allow for an accurate comparison with non-athlete students; that the metrics did not acknowledge how unprepared college athletes were impacted by the different missions and overall quality of students varying in size and available resources; and that the standards encouraged academic fraud when inadequate remedial support services were provided to under-prepared student-athletes (Gurney et al., 2015). Not unexpectedly, the source of much criticism on behalf of individuals and groups revolved around the impact of the NCAA measures on African American student-athletes. For instance, Derrick Z. Jackson, an award-winning Black journalist, accurately noted in a 2018 issue of The Undefeated that the continued disparities between the graduation rates of Black and White athletes and the NCAA's refusal to not only acknowledge the gulf, but to pretend it does not exist exposed the claim of "how college sports helps more and more minority students" as being patently erroneous (Jackson, 2018).

There were other critics. Monique Ositelu, a senior policy analyst of higher education with New America's Education Policy Program, correctly wrote in a 2019 volume of Diverse Issues in Higher Education, that Historically Black Colleges and Universities (HBCUs) had as low-resourced institutions been disproportionately penalized by the APR. Unlike wealthy and generously endowed larger universities, which can afford to place at-risk athletes on institutional scholarships rather than athletic ones and therefore "increase their teams' APR scores and create a false sense of academic progress," HBCUs lacked the financial resources to selectively distribute athletic aid in an effort to raise APR scores and avoid NCAA penalties and the inevitable public scrutiny that typically accompanied it (Ositelu, 2019). Brand certainly would have been distraught by Ositelu's analysis. He had expressed on multiple occasions, perhaps more than any NCAA president before or after his tenure, support for HBCUs and desired to see that athletes representing those institutions were successful academically and enjoyed meaningful and fulfilling careers following graduation. In a joint 2008 interview with Charlotte Westerhaus, Brand acknowledged the important role played by HBCUs in providing opportunities to local communities and economically disadvantaged students, and recognized HBCUs as institutions that furnished positive and nurturing environments. He also noted the financial constraints faced by HBCUs and lauded the grant program established by the NCAA 
to help Black schools alleviate fiscal concerns as much as possible (Brand, 2008b).

Besides sustained attempts at academic reform, Brand and the NCAA did all they could to encourage member institutions to rid themselves of the use of Native American mascots and images. In February 2006 the Executive Committee of the NCAA handed down a policy stipulating that any member institution that used "offensive or hostile imagery" depicting Native Americans would be barred from hosting championship events. A policy that Brand noted "was over four years, almost five years in the making," and after consultation with "80 national Native American organizations" and the Commission on Civil Rights," was not without controversy, however. Critics claimed, among other things, that the new policy was implemented in an inconsistent fashion (Brand, 2006b, p. 60). One example critics pointed to is the case of the Florida State University Seminoles, which the NCAA initially put on its list of schools for potential sanctions for its use of "very hostile and abusive" Indian mascots and names but eventually exempted the university from any discipline because of its close relationship with the Seminole tribe. "Because the Florida Seminole Tribe has made an explicit decision and participated in the images that they [Florida State] use and said this is acceptable," noted Brand. "And surely we have to defer to those Native American tribes who feel that way" (Brand, 2006b, p. 64).

In spite of the critics, the NCAA policy against the offensive caricatures and stereotypes of Native Americans in the form of nicknames and mascots has proven to be largely successful. In 2013, the National Congress of American Indians reported that 2,000 Indian "references in sports have been eliminated in the past 35 years, with about 1,000 remaining today" (Rogers, 2013). Importantly, those colleges and universities that have done away with Native American mascots and images have generally done well financially in the long run. Manish Tripathi and Mike Lewis, two sport management scholars from Emory University, concluded from their research that those colleges and universities that eliminated Native American mascots felt the financial pinch for one or two years but this disappeared in the long term. Utilizing data from the Equity in Athletics Disclosure Act, Lewis and Tripathi concluded that NCAA basketball teams that removed Native American mascots over the last four decades realized a "long-term positive financial impact" (Lewis \& Tripathi, 2013).

Brand complemented his efforts at banishing Native American Indian mascots and imagery with a visible and concerted campaign to secure more head coaching positions for African Americans, particularly in football, which has always had a dearth of minorities in charge of teams. He helped establish, with assistance of the Black Coaches Association (BCA), three coaching academies to assist African Americans in securing coaching positions. Brand also utilized the most public forums to urge the hiring of Black coaches. Although by all accounts a "soft-spoken, unpretentious, even shy person," Brand willingly spoke out via various forms of the media, just as he had done with so many other issues in an effort to keep the NCAA more visible to member institutions and the general public, about the paucity of African American football coaches (Dunn, et al., 2010, p. 189). He did it, for example, in interviews published in major newspapers such as the The New York Times and through "Mondays with Myles," a popular podcast created by Josh Centor, the 
NCAA's Coordinator of New-Media Communications. In a blunt assessment regarding the limited number of minority coaches in football, Brand told Centor in a 2007 episode of the podcast that:

it [the lack of Black coaches] is a very serious problem and it's a frustrating problem, too, because we have not been making a kind of progress I think we ought to make. It's a problem about which I spoke many times in the last four years that I've been here, but nonetheless it's proved to be very close to intractable at this point (Brand, 2007a, p. 110).

Brand's seriousness about the lack of minority coaches was made evident through his engagement with the BCA and its Executive Director Floyd Keith. He worked closely with the organization on an issue that was obviously close to his heart. Just a year after he was appointed President of the NCAA, Brand delivered the keynote address at the BCA Images of Excellence Luncheon. In the address, he provided one of his most comprehensive assessments and offered possible solutions to the lack of both Black coaches and Black upper-level administrators in college sport. Aside from the dramatic increase in the number of African American head coaches in Division I male basketball, Brand observed, "men and women of color are simply not being hired in head coaching jobs or administrative positions in intercollegiate athletics in an equitable way" (Brand, 2003a, p. 6). Excluding the number of Black administrators at HBCUs, Brand pointed out there were only 29 African American men and three African American women in athletic director positions in all divisions in intercollegiate sport. The numbers for head coaching jobs was not much better. Of approximately 14,000 head coaching positions, again excluding those at HBCUs, African American males held 737 of those positions and African American women just 165 .

To reverse these numbers, Brand suggested, among other things, that university presidents develop and embrace clear guidelines for job searches that would lead to the identification of minority candidates and ensure they would be treated fairly. Specifically, he recommended that searches for head coaches and athletic directors be conducted in a similar fashion to those conducted for academic positions. Such a practice would entail the creation of a "representative search committee" consisting of faculty and university administrators as well as athletic department members; emphasize an intentional effort to identify minority candidates; insist that the search committee "personally interview the leading candidates" to ensure their ability to field highly successful teams, promote academic success among student-athletes, and effectively represent the university and its various constituencies; and require that search committees submit a short list of three to five candidates to university presidents for his/her final decision. This approach, Brand emphasized, would put the final decision on the hiring of coaches and athletic administrators squarely in the hands of university presidents and not athletic departments, which often "restrict the pool of candidates to a small network of known individuals" and "leads to appointments that lack diversity" (Brand, 2003a, pp. 21, 24).

Brand reiterated many of these suggestions during his testimony in a 2007 House of Representatives subcommittee session on "The Lack of Diversity in Leadership 
Positions in NCAA Collegiate Sports" (House of Representatives, 2007). Chaired by John D. Dingell of Michigan and including other witnesses such as Richard Lapchick, Jesse Jackson, president of the Rainbow/Push Coalition, and Nolan Richardson, former head basketball coach at the University of Arkansas, Brand delivered a prepared statement and answered several pointed questions posed by House members. He made clear once again his disappointment that more African Americans had not been hired as head coaches in football, pointing out the frustratingly low number of African Americans who had assumed such positions over the previous four years at the Division IA level or the Bowl Championship Subdivision. He repeated, as he would many times over during his tenure as President of the NCAA on this issue and others, the crucial role that university presidents played in identifying and hiring African Americans as head coaches in football. He made explicit that the NCAA could not mandate who was interviewed and ultimately hired as coaches in intercollegiate athletics. That power resided with member institutions, under the leadership of their presidents. Increasing the number of minorities in the profession, Brand emphasized, fell to colleges and universities, not the NCAA (House of Representatives, 2007).

Echoing points made in his writings, interviews, and other forms of communication about the lack of minority coaches, Brand suggested during his testimony that he was most encouraged by the efforts of the BCA. Having a great deal of respect and a good working relationship with BCA Executive Director Floyd Keith, Brand effusively praised the organization. He lauded the various initiatives implemented by the organization to increase the number of African Americans and other minorities in head coaching positions. He was especially praiseworthy of the BCA's hiring report card - a formula he frequently compared favorably with the Rooney Rule in the National Football League - that graded colleges and universities on the progress they made regarding the number of minorities interviewed and hired for coaching positions. Although continuing to be disappointed by the scarcity of minorities in the profession, he pointed out to the subcommittee that as a consequence of the BCA's public disclosure of its grades,

more than 30 percent of all candidates interviewed for head coaching positions over the last 3 years have been minorities. Even more striking is that 76 percent of all the openings over the last 3 years have had at least one minority candidate interviewed and more than three out of every four vacancies, a person of color was interviewed (House of Representatives, 2007, p. 15).

Brand's subcommittee testimony, unfortunately enough, would prove to be overly optimistic. Indeed, he would have been distraught by the number of Black head coaches currently in college sport, especially football and men's basketball. The latest numbers regarding Black head coaches and key coordinating positions from the 130 Football Bowl Subdivision (FBS) schools are appalling and would lead one to believe that the sport will never reach the minority representation on the sidelines that it has reached on the playing field. Among the 130-member FBS teams, only 11 of them will be led by African American head coaches entering the 2021 season, a decline from just 15 years ago and reflecting an underrepresentation similar to 
the National Football League, which has only three African American head coaches among 32 teams (Associated Press, 2021). The number of African American head coaches in college basketball is just as dismal. Only 22.7 percent of the head coaches at the Division I level are African American. Of the 77 teams in the Power Six Conferences of college basketball (ACC, Big 12, Big East, Big Ten, PAC 12, and SEC) only 13 of them are led by African Americans (Nerkar, 2021).

The possible reasons for the small number of head coaches in college football and men's basketball are multiple and varied. Tellingly, similar to Brand, some people laid blame for this unfortunate situation partly on the search process but not exactly in the way he had envisioned it. In college basketball, according to these critics, a primary reason for the small number of Black coaches has to do with the increasing use of search firms. As one Black head coach recently told NBC Sports, "white presidents hire white search firms to hire white AD's who hire those same white search firms to hire white head coaches" (Dauster, 2020, p.4). Exacerbating the problem, many of those same coaches suggest that athletic directors, who are increasingly coming from the world of business, tend to play it safe by repeatedly hiring the same white coaches rather than giving quality Black assistants, who are stereotyped as recruiters with the requisite skills to relate to players and their parents from urban backgrounds, a chance. Rarely are qualified Black assistant coaches viewed as possessing the know-how to develop players and relate to administrators and boosters. The result is that many White coaches have been recycled through the system while their Black colleagues are left waiting for job offers that never come.

The concerted effort Brand put into securing more Black head coaching positions in college athletics, which proved to be far more difficult than perhaps even he had imagined, would be duplicated in his attempts to see that women were provided the same access to college sport as their male counterparts. Relatively speaking, he was more successful here, largely as a result of the support of the federal government in defending the rights of women to participate in intercollegiate sport. Title IX is the prime example. Always controversial, Title IX has prompted numerous challenges - almost from the moment it was signed into law by Richard Nixon in 1972. Some of the most heated challenges garnering national attention were court cases filed on behalf of male athletes who argued that the elimination of their teams had been a direct result of the legislation (Brake, 2010; Hogshead-Makar \& Zimbalist, 2007; Suggs, 2005).

The one men's sport that was perhaps most connected to Title IX was wrestling, which had seen many of its programs, some of them very prestigious and long-standing, terminated at various institutions across the country. In 2002, the National Wrestling Coaches Association (NWCA), after witnessing the failed lawsuits filed on behalf of individual college wrestling programs, filed its own suit against the Department of Education (DOE). In essence, the lawsuit alleged that colleges, because they were unable to add more women's team due to women's limited interest in sports, were unfairly "eliminating or limiting the size of men's teams" to reach proportionality requirements mandated by Title IX (Ridpath et al., 2009, pp. 264-265). The DOE dismissed the claim, noting there was no indication that Title 
IX policies had caused the elimination of men's wrestling programs. The NWCA would, in turn, unsuccessfully appeal the decision to the DC Circuit Court of Appeals and the U.S. Supreme Court. Undeterred, wrestling advocates then decided to lobby the DOE and the new George W. Bush administration in an effort to overturn Title IX guidelines. The DOE, headed up by Bush appointee Rod Paige, responded by establishing the Commission on Opportunity in Athletics to study the issue and offer recommendations as to whether changes should be made to the guidelines. With 10 of the 15 commissioners representing NCAA Division I colleges with large football programs and the fact that the majority of witnesses invited to testify in hearings only spoke about the reduction in men's programs rather than those lost by women, it came as no surprise that the Commission issued a report calling for rollbacks in Title IX guidelines that arguably went against the statute itself (Ridpath et al., 2009). Fortunately, two prestigious members of the Commission, legendary swimmer Donna de Varona and soccer star Julie Foudy, wrote a minority opinion opposing most of the recommendations. Groups such as the National Coalition on Women and Girls in Education and the American Bar Association expressed their opposition as well. Ultimately, because of Paige's decision to accept only those recommendations that received unanimous support, the DOE opposed adopting most of the suggestions. In July 2003, the Director of the Office for Civil Rights (OCR) distributed a letter titled "Further Clarification of Intercollegiate Athletics Policy Guidance Regarding Title IX Compliance" in which it opposed the most harmful proposals (Grossman, 2010).

Concerted efforts on the part of the NWCA, the executive branch, and others to alter Title IX guidelines were deeply troubling to Brand and he expressed it on multiple occasions. For instance, approximately three months prior to the OCR issuing its letter, Brand staunchly defended Title IX guidelines in what was referred to as a "Title IX Seminar Keynote Address" (Brand, 2003b). Full of data, thoughtful reasoning, and careful analysis, the Address was both a passionate defense of Title IX and another window into Brand's belief in the power of sport to impart values and teach positive character traits that can be carried over into other aspects of one's life. He noted how impactful Title IX had been since it came into existence, citing the fact that there were now some 150,000 women competing in intercollegiate athletics; that the NCAA was sponsoring 19 championships in women's sports; and that female athletes were receiving approximately 42 percent of available scholarship money. He also pointed out that when schools eliminated specific sports programs it was an institutional decision rather than a result of Title IX guidelines. To Brand, far too many schools had unfairly used Title IX as an excuse when sports programs were eliminated, unwilling to acknowledge that the means to achieve gender-equity in intercollegiate athletics was based on institutional priorities and choices regarding the allocation of resources. He emphasized and provided examples, moreover, of women who took advantage of the opportunities afforded by Title IX, excelled as college athletes, and then went on to distinguished careers whose skills and character traits could only be learned through sport. Among those women mentioned by Brand were Robin Roberts, outstanding college basketball player and television broadcaster; Dot Richardson, Olympic softball player and Orthopedic surgeon; Anita 
DeFrantz, medal winning Olympic rower, United States Olympic Committee member, and Executive Director of LA 84; and Ann Meyers Drysdale, UCLA basketball standout and television broadcaster. Of the athletes he quoted in support of Title IX, it was certainly no coincidence that Brand chose University of Arizona President Peter Likins who wrestled while an undergraduate student at Stanford. Not many people were more credible to defend Title IX than the highly respected Likins, president at a Research 1 institution who had competed competitively in the one sport that so aggressively opposed the statute. "As an old wrestler (Stanford '57), I have been deeply saddened by the wholesale elimination of wrestling teams under Title IX," noted Likins (Brand, 2003b, p. 5). He went on:

However, I assign fault to male leadership, and not to Title IX. We have as a national society decided that we prefer to allocate the fair distribution of opportunities for male athletes in a peculiar way, assigning very large numbers of these opportunities to one sport and correspondingly contracting the number of men's sports we can sponsor within economic constraints (Brand, 2003b, p. 5).

Unfortunately, in 2005, the OCR, with no prior notice or public pronouncement, issued another "clarification" on Title IX that authorized universities to distribute e-mail surveys to women students so as to determine their level of interest in athletics (Grossman, 2010). A blatantly underhanded attempt to satisfy the third prong of the Title IX guidelines requiring schools to offer women's athletic programs proportional to the level of interest in athletics as shown by women in the general student body, the surveys demonstrated the lengths to which Title IX's opponents would go to weaken the law. The OCR, knowing full well the limited response rate to such methods of data collection, shamefully noted that not responding to the survey would indicate a lack of interest in participating in intercollegiate athletics. Two years later, the OCR held a hearing on Title IX for the express purpose of affirming the DOE's right to use e-mail surveys to assess women's interest in participating in intercollegiate athletics (Kuznick, 2007).

Brand was appalled by these efforts to circumvent Title IX guidelines through obviously unreliable e-mail surveys (It was not until 2010, a year after Brand's death, that then Vice President Joe Biden would announce the elimination of this loophole in DOE policy regarding enforcement of Title IX). Evidence of Brand's disapproval can be gleaned from the NCAA's formal resolution in 2005 opposing student interest surveys on the grounds that the DOE had adopted the policy without input from other interested groups and that it violated "principles of equity under Title IX" (Grossman, 2005, p.4). More pointedly, the NCAA argued that the use of surveys themselves “conflicts with a key purpose of Title IX-to encourage women's interest in sports and eliminate stereotypes that discourage them from participating and shifts the burden to female students to show that they are entitled to equal opportunity" (Grossman, 2005, p.4). Brand referenced the resolution and made explicit his opposition to the DOE policy in a May 2007 "Monday with Myles" interview with Josh Centor. "We don't believe, and in fact, the Executive Committee of the NCAA sent out a very strongly worded letter," Brand told Centor. He continued: 
We don't believe that that reflects a good way of accounting for interest to the underrepresented gender. Moreover, we don't believe that this will, in fact, be a reasonable way to defend yourself in court if you are, in fact, out of compliance with Title IX (Brand, 2007b).

In all, Brand, and by extension the NCAA, experienced mixed results when it came to academic reforms, ridding college sport of Native American Mascots and imagery, increasing the number of Black head coaches, and maintaining the integrity of Title IX policies. Although impactful in an assortment of different ways regarding diversity, inclusiveness, and social justice, the one area in which Brand seemed to be most ineffective during his tenure as NCAA President was convincing member institutions to hire Black head coaches (Brand, 2007c; 2009b). With the assistance of university presidents and others, Brand successfully led the fight for academic reforms in intercollegiate sport, albeit a system still fraught with limitations and problems, and the elimination of offensive Native American Mascots and images. Ultimately, with the backing of governmental legislation, Brand's efforts to uphold the original intent and policies of Title IX would generally prove more effective, although a variety of factors resulted in the decline of women coaches and African American women athletes in many sports. With the notable exceptions of basketball and track and field, African American women are still underrepresented in most sports at the intercollegiate level.

The dearth of Black head coaches in college sport, however, seemed to be an entirely different matter. In spite of his efforts to encourage the hiring of more Black head coaches, a fact acknowledged posthumously in 2010 when the Black Coaches Association renamed its signature Administrator of the Year award after him, Brand had a particularly difficult time in motivating member institutions to interview, let alone secure, the services of minority candidates in such positions. Brand alone could not overcome both the racial segregation and assumptions that govern the culture of the head coaching ranks in college sport - a situation that sadly shows no sign of changing any time soon. Brand alone could not eliminate the racialist thinking and racism that pervades all levels of sport and society more generally. These facts should not diminish Brand's reputation as a principled and morally upstanding person, who was "a courageous and visionary leader, deeply committed to many ideals, including fairness and equality, academic reform, and academic excellence." (Dunn et al., 2010, p.190).

Tellingly, Brand's reputation as a "courageous and visionary leader" has only grown over time, particularly when compared to his predecessors as well as his immediate successor, Mark Emmert, who continues to guide the NCAA to this day. In fact, in some ways, Brand seemed to be decidedly different than the organization's other Presidents. Although many examples could be provided to indicate the essential differences between them, including Brand's unparalleled level of transparency as evidenced by his creation of the NCAA Scholarly Colloquium among other things, what seems most important is to ascertain what accounted for Brand's commitment to diversity, inclusiveness, and social justice. ${ }^{1}$ It is not a question that can be answered with any degree of certainty, but there seems little doubt it could not 
have been any other way for a man who would remain the quintessential philosopher throughout his long and distinguished academic and administrative career. Humble, curious, and lover of knowledge, Brand was an idealist always seriously concerned with what constituted the good life, questions of right and wrong, and importance of democratic principles. These concerns were manifested, in turn, in his dedication to insuring that everyone, irrespective of race, gender, and economic and cultural background, had fair and equal access to college sport and the many benefits that resulted from participating in it. He was too modest to probably feel comfortable with such a moniker, but it is no exaggeration to state that Brand, albeit for too short a period of time, was the conscience of college sport.

\section{Notes}

${ }^{1}$ Brand introduced the NCAA Scholarly Colloquium in 2008 as a way to encourage more research on various aspects of intercollegiate athletics. The colloquium, which was a two-day event held prior to the annual NCAA conference, brought together prominent scholars who delivered presentations on a wide variety of topics dealing with college sport. Always a nicely organized event that spurred insightful discussion and thoughtful dialogue, the colloquium was cancelled by the NCAA in 2013 for reasons that are not entirely clear. For information about the colloquium, see Brown (2011), Kretchmar (2013), and Steinbach (2013).

\section{Acknowledgements}

I would like to thank Chris Elzey for his cogent comments and helpful suggestions on an earlier draft of this manuscript.

\section{References}

Associated Press (2021). Black coaches left behind again during hiring season. Wtopnews. https://wtop.com/ncaa-football/2021/01/column-black-coaches-left-behind-again-during-hiring-season/

Brake, D. (2010). Getting in the game: Title IX and the women's revolution. New York University Press.

Brand, M. (2001, January 23). Academics first: Reforming intercollegiate athletics: Remarks to the National Press Club. https://mylesbrand.com/wp-content/ uploads/2001/01/National-Press-Club-2001.pdf

Brand, M. (2003a, June 5). Keynote Address, Black Coaches Association's Images of Excellence Luncheon. https://mylesbrand.com/wp-content/uploads/2003/01/2003-BCA-keynote-speech-6-5-2003.pdf

Brand, M. (2003b, April 28). Title IX Seminar Keynote Address. https://mylesbrand.com/wp-content/uploads/2003/01/Brand-NCAA-Title-IX-Keynote-Address-2003.pdf 
Brand, M. (2006a, March 1). NCAADivision I APR with Myles Brand, Walt Harrison, and Eric Christianson. https://mylesbrand.com/wp-content/uploads/2006/01/31-2006-NCAA-Division-I-APR-with-Myles-Brand-Walt-Harrison-Eric-Christianson-1.pdf

Brand, M. (2006b, April 10). Mondays with Myles, Episode 10. Mascot and nickname policy. https://mylesbrand.com/wp-content/uploads/2006/01/4-10-2006Mascot-and-Nickname-Policy.pdf

Brand, M. (2007a, February 26). Mondays with Myles, Episode 45. Race and athletics. https://mylesbrand.com/wp-content/uploads/2007/01/2-26-2007-Race-Athletics-Hiring.pdf

Brand, M. (2007b, May 21). Monday with Myles, Episode 57. Thirty-five years of Title IX. https://mylesbrand.com/wp-content/uploads/2007/01/5-21-2007-35Years-of-Title-IX.pdf

Brand, M. (2007c, January 29). NCAA urges, but can't compel hiring of black coaches. The Indianapolis Star. https://mylesbrand.com/wp-content/ uploads/2007/01/2007-NCAA-urges-but-cant-compel-Indy-Star-1-29-2007.pdf

Brand, M. (2007d, April 16). Mondays with Myles, Episode 52. HBCU's. https://mylesbrand.com/wp-content/uploads/2007/01/4-16-2007-HBCUs.pdf

Brand, M. (2008a, January 21). Mondays with Myles, Episode 88. Social justice. https://mylesbrand.com/wp-content/uploads/2008/01/1-21-2008-Social-Justice. pdf

Brand, M. (2009, April 10). Diversity hiring is right, smart. Huffington Post. https:// mylesbrand.com/wp-content/uploads/2021/02/4-10-2009-Huffington-PostDiversity-II.pdf

Brennan, C. (2009). NCAAs Brand was the strongest figure in college sports. USA Today. https:/usatoday30.usatoday.com/sports/columnist/brennan/2009-09-16myles-brand N.htm

Brown, G. (2011 July 19). Papers sought for 2012 scholarly colloquium. NCAA News. https://ncaanewsarchive.s3.amazonaws.com/2011/july/papers-sought-for-2012-scholarly-colloquium.html

Coakley, J. (2021). Sports in society: Issues and controversies. McGraw Hill.

Dauster, R. (2020). It's very disappointing: The number of black head coaches continues to fall at college hoops highest level. NBC Sports. https://collegebasketball.nbcsports.com/2020/03/03/its-very-disappointing-the-number-of-blackhead-coaches-continues-to-fall-at-college-hoops-highest-level/

Drape, J. (2005, March 16). New study shows gap on court and in class. The New York Times.

Duderstadt, J. (2000). Intercollegiate athletics and the American university; A president's perspective. University of Michigan Press.

Dunn, J.M., Hanson, K., Lehrer, K., Ryan, C., Swain, M., \& Tilley, J. (2010). Myles Neal Brand, 1942-2009. Proceedings and Addresses of the American Philosophical Association, 84 (2), 188-190. http://www.jstor.org/stable/25769946

Grossman, J.L. (2010). Defending quality in athletics: The Obama administration repeals a controversial Bush era policy. https://supreme.findlaw.com/le- 
gal-commentary/defending-equality-in-athletics-the-obama-administration-repeals-a-controversial-bush-era-policy.html

Gurney, G., Lopiano, E., Snyder, D., Willingham, M., Meyer, J., Porto, B., Ridpath, D.B., Sack, A., \& Zimbalist, A. (2015-Revised 2017, 2019, 2021.) The Drake Group Position Statement: Why the NCAA Academic Progress Rate (APR) and Graduation Success Rate (GSR) should be abandoned and replaced with more effective academic metrics. https://thedrakegroup.org/2015/06/07/ drake-group-questionsncaa-academic-metrics/

Hamilton, K. (2005). Putting the student back into student-athlete, Black Issues in Higher Education, 22 (4), 28-30. https://mylesbrand.com/wp-content/ uploads/2005/01/2005-Putting-the-Student-Back-into-Student-Athlete.pdf

Hogshead-Makar, N., \& Zimbalist, A. (2007). Equal play: Title IX and social change. Temple University Press.

House of Representatives (2007). One hundred tenth congress, first session, the lack of diversity in leadership positions in NCAA collegiate sports: Hearing before the subcommittee on commerce, trade, and consumer protection of the committee on energy and commerce. https:/www.Loc.gov/item/2007395912/

Hutchens, T. (2009, September 16). Brand, Knight forever linked by coach's dismissal at Indiana. Indianapolis Star. https://usatoday30.usatoday.com/sports/ college/2009-09-16-brand-knight-indiana_N.htm

Hylton, J.G. (2009, Septembr 18). Myles Brand and the illusion of reform. Marquette University Law School Faculty Blog. https://law.marquette.edu/facultyblog/2009/09/myles-brand-and-the-illusion-of-reform/

Jackson, D.Z. (2018, December 26.). NCAA needs a reality check when it comes to grad rates for black athletes. The Undefeated. https://theundefeated.com/features/grad-rates-for-black-athletes-ncaa-needs-a-reality-check/

Kelley Indianapolis (2019, August 19). Hub. https://hub.kelley.iupui.edu/blog blog/ resilience-and-grit-charlotte-westerhaus-renfrow-lives-the-principles-of-herwork.html

Kretchmar, R.S. (2013, January 21). Lack of support for scholarly colloquium a loss for NCAA. Donald P. Bellisario College of Communications. https://www.bellisario.psu.edu/news/article/lack-of-support-for-scholarly-colloquium-a-lossfor-ncaa

Kuznick, L. (2007). Bush-big backer of Title IX-Yeah right. National Women's Law Center. https://nwlc.org/blog/bush-“big-backer”-title-ix-yeah-right/

Lapchick, R. (2009). Brand: A friend in the justice world. UCF Today. https://www.ucf.edu/news/brand-a-friend-in-the-justice-world/

Lewis, M., \& Tripathi, M. (2013, May 7). An imperfect analysis of the economics of Native American mascots: Much ado about nothing? Emory University Faculty Blog. https://scholarblogs.emory.edu/esma/2013/05/07/an-imperfect-analysisof-the-economics-of-native-american-mascots-much-ado-about-nothing/

Lippold, K. (2007, October 5). NCAA president Myles Brand speaks on the place of intercollegiate athletics in American culture. https://www.hamilton.edu/news/ story/ncaa-president-myles-brand-speaks-on-the-place-of-intercollegiate-athletics-in-american-culture/ 
Litsky, F. (2003, March 25). Study finds top teams failing in the classroom. The New York Times. https://www.nytimes.com/2003/03/25/sports/2003-ncaa-tournament-academics-study-finds-top-teams-failing-in-the-classroom.html

Nerkar, S. (2021, March 26). Only 13 black coaches led major men's basketball programs this year. Two face off in the sweet sixteen. Five Thirty Eight. https:// fivethirtyeight.com/features/only-13-black-coaches-led-major-mens-basketball-programs-this-year-two-face-off-in-the-sweet-16/

Ositelu, M.O. (2019, June 16). NCAA's discriminatory APR scores. Diverse Issues in Higher Education. https://diverseeducation.com/article/147792/

Pennington, B. (2009, September 19). A diplomat and a reformer, but an educator to the core. The New York Times. https://www.nytimes.com/2009/09/20/ sports/20brand.html

Ridpath, B., Yiamouyiannis, A., \& Lawrence, H. (2009). Changing sides: The failure of the wrestling community's challenges to title ix and new strategies for saving NCAA sport teams. Journal of Intercollegiate Sport, 1(2), 255-283.

Rogers, M. (2013, December 10). Mascot makeover. Inside Higher Ed. December 10, 2013 https://www.insidehighered.com/news/2013/12/10/most-colleges-adjust-moving-away-native-american-mascots

Shulman, J., \& Bowen, W. (2001). The game of life. Princeton University Press.

Smith, R.A. (2011). Pay for play: A history of big-time college athletic reform. University of Illinois Press.

Steinbach, P. (2013, March 14). Scholars react to cancellation of NCAA colloquium. Athletic Business. https://www.athleticbusiness.com/scholars-react-to-cancellation-of-ncaa-colloquium.html

Suggs, W. (2005). A place on the team: The triumph of Title IX. Princeton University Press.

Wiggins, D. K., \& Miller, P. B. (2003). The unlevel playing field: A documentary history of the African American experience in sport. University of Illinois Press.

Wiggins, D. K. (2018). More than a game: A history of the African American experience in sport. Rowman \& Littlefield. 